\title{
Factors Affecting the Adoption of Computer Assisted Audit Techniques in Audit Process: Findings from Jordan
}

\author{
Ebrahim M. Mansour \\ Department of Accounting, the Hashemite University \\ P.O. Box 330127, Zarqa 13133, Jordan
}

Tel: 962(5)-390-3333Ｅ-mail: ebrahim_mansour@hu.edu.jo

Received: February 9, 2016 Accepted: March 8, 2016

doi:10.5296/ber.v6i1.8996 URL: http://dx.doi.org/10.5296/ber.v6i1.8996

\begin{abstract}
Despite the efforts of auditing professional bodies to help stimulating the application of contemporary audit technologies among audit firms to cope with the rapid growth in information technology usage among business organization, the extent to which Jordanian external auditors and alongside the world's trend have accepted Computer Assisted Auditing Techniques (CAATs) remains fairly low. This study use the Unified Theory of Acceptance and Use of Technology (UTAUT) to explore this lack of CAATs' usage in Jordan and try to find answer to what factors may affect their adoption and acceptance. The study has drawn upon qualified questionnaire sent to 200 statutory external auditors to obtain the data. With a response rate over $80 \%$, the results of the statistical analysis revealed that Jordanian external auditor's intention to adopt CAATs may be driven by both auditor's performance expectancy and firm's facilitating conditions issues. However, effort expectancy and social influence at the other spectrum may not play such a major role. These results have several practical implications. Jordanian audit firms can create a positive attitude amongst its auditors towards CAATs' usage by promoting CAATs benefits and usefulness, by decreasing efforts expectancy needed to use CAATs, and by further investing in management and technical infrastructure supporting CAATs.
\end{abstract}

Keywords: Computer Assisted Auditing Techniques, Unified Theory of Acceptance and Use of Technology, External Auditors, Jordan

\section{Introduction}

Over the last few years, and due to the benefits that information technology (IT) can convey 
to business and public organizations, the world has exhibited unprecedented growth of public and private investments in IT (Laudon \& Laudon, 2016). Many businesses are reengineering their business models toward e-business and increasingly implementing sophisticated and complex IT's applications including advanced computerized accounting information systems (AIS) (Romney \& Steinbart, 2015; Shaikh, 2005). This rapid advances in IT's usage by business organization has altered the means by which they collect and disclose financial information. They are in fact experiencing numerous and complex IT's sets that preserve data on an electronic media rather than paper-based one (Arens, Elder, \& Beasley, 2014; Foneca, 2003; Khemakhe, 2001; Zhao, Yen, \& Chang, 2004). Auditors of these businesses are consequently encountered with huge challenge of working and keeping up to date with such complicated environment (Mahzan \& Lymer 2014; Shaikh, 2005). They must understand how the company uses information systems to collect, record, process and report financial transactions or other data as well as how to trace electronic source documents (Arens, Elder, \& Beasley, 2014; Bedard, Jackson, Ettredge, \& Johnstone, 2003; Bierstaker, Burnaby, \& Thibodeau, 2001; Shaikh, 2005). This understanding is highly needed to plan the audit and to determine the tests to be performed to have better and sufficient understanding of internal controls and to execute reliable financial reports audit (Bierstaker, Burnaby, \& Thibodeau, 2001; Curtis \& Payne, 2008; Janvrin, Bierstaker, \& Lowe, 2009; Rosli, Yeow, \& Siew, 2012).

To meet these auditing concerns and to respond to this phenomenon, several recent audit standards recommend auditors to implement Computer Assisted Audit Techniques (CAATs) to perform audit jobs and tasks efficiently and effectively (AICPA, 2001, 2002a, 2002b, 2002c, 2006; PCAOB, 2007, 2010a, 2010b; IFAC, 2009; SAS No. 99).

CAATs are audit technologies that can help both internal and external auditors to perform audits' tests and tasks in audit jobs (Braun \& Davis, 2003; Saygili, 2010). CAATs range from simple procedures as electronic working papers to the use of statistical analysis software and Artificial Intelligence tools to predict financial failure or fraudulent financial statement (Braun \& Davis, 2003; Grand, 2001a; Grand, 2001b; Hall, 2016; Jaksic, 2009).

The claimed benefits for auditors and audit firms to use CAATs include, reducing audit cost, improving audit quality and productivity, supporting timely audit report and enhancing audit effectiveness and efficiency (Dowling \& Leech, 2007; Zhao, Yen, \& Chang, 2004). CAATs for example are permitting auditors to conduct manual intensive tasks quickly, to perform tests of internal controls described in the Public Company Accounting Oversight Board (PCAOB), to improve control effectiveness required under Section 404 of the Sarbanes-Oxley Act and to enhance responsibilities to detect fraud required by SAS No. 99 (AICPA 2001; AICPA 2006; Banker, Hsihui, \& Yi-Ching, 2002; Curtis \& Payne, 2008; PCAOB 2004a, 2010c; Singleton, 2011).

Notwithstanding the benefits of CAATs and the efforts of auditing standards setters to help encouraging the application of contemporary audit technologies among auditors and audit firms, research shows that auditors do not often and steadily use CAATs and less effort is made to incorporate up-to-date audit software in the audit process particularly among external auditors (Aidi \& Kent, 2013; Debreceny, Lee, Neo, \& Toh, 2005; Janvrin, Bierstaker, \& 
Lowe, 2009; Kalaba, 2002; Liang, Lin, \& Wu, 2001; Payne \& Curtis, 2010; Shaikh, 2005).

Within the Jordanian context, the country is witnessing a progressive action towards Information and Communication Technology's (ICT) readiness (Al-Shboul \& Izzat, 2010; World Economic Forum, 2010). Jordan has established many initiatives concentrating on e-Business, implementation of computer-based AIS among Jordanian business organizations, development of legal framework and commitment to International Financial Reporting Standards (IFRS) and International Standards on Auditing (ISAs) (Al-Farah, Abbadi, \& AL Shaar, 2015). However, despite these emerging and accelerated initiatives, which should motivate Jordanian auditors to utilize the latest audit techniques (i.e., CAATs), many reports and alongside the world's trend, indicated that there is little evidence regarding CAATs' adoption (Al-Farah, 2011; Khaddash \& Siam, 2003; Thnaibat, 2003). Given CAATs' potential and public expectation for quality of audit process, understanding the drivers of CAATs' acceptance and adoption becomes increasingly important. This understanding would have particular policy implications for Jordanian educational and professional bodies that are interested in enhancing the effectiveness and efficiency of the auditing profession (Al-Farah, 2011; Braun \& Davis, 2003; Zhao, Yen, \& Chang, 2004).

Recognize this deficiency, the current study draws on prior research in accounting, information systems and social behavior to fill this gap by examine the factors that might lead Jordanian external auditors to choose to use new technology in the course of their professional responsibilities. Key research question that motivates this work is: What factors may affect Jordanian external auditors' intention to utilize and adopt CAATs in undertaking their audit activities?

The remainder of the paper is organized as follows. The following section reviews the relevant literature, on which the conceptual model is developed and research hypotheses are then presented, followed by research method, analysis, and results. The paper concludes with a discussion of research findings, implications, limitations, and areas for further research.

\section{Background and Literature Review}

\subsection{The Use of Technology in Auditing}

Public accountants have provided audits, a traditional attestation service, for a decades. However, by the power of the contemporary information systems that are being developed and used by business organizations, the methods they use to capture, store, process, report and publish financial information have changed dramatically (Rezaee \& Reinstein, 2001; Shaikh, 2005). This increase of information technology usage in the businesses auditors are working within, has confronted auditors with risen complexity, serious concerns and risks regarding data to be obtained from the client's information systems, loading these data (online or offline) into the audit software, and then planning and completing the internal controls and audit tests (Curtis \& Payne, 2014; Hall, 2016). In addition, the disappearing of traditional paper trail from the workplace and the increasing in electronic evidences, require the auditors to implement IT techniques in the entire auditing process and to use up-to-date auditing technology tools to cope with the developments of the underlying businesses they audit 


\section{MInstitute Macrothink $_{\text {Int }}$}

Business and Economic Research

ISSN 2162-4860

2016, Vol. 6, No. 1

(Braun \& Davis, 2003; Devaraj \& Kohli, 2003; Dowling \& Leech, 2007; Janvrin, Bierstaker, \& Lowe, 2009; Khemakhe, 2001). Bierstaker, Burnaby, and Thibodeau (2001) indicated that IT is indispensable for auditors to understand the client's business processes, to cope with the new paperless environment as well as to understand how IT sophistication affects the nature of audit testing. In addition, Rosli, Yeow, and Siew (2012) specified that auditors have to accumulate and assess audit evidence to examine whether the AIS has processed business transactions correctly while maintaining data integrity, validity and accuracy of the information generated. To conclude, in this technology driven business environment, auditors need more guideline, diverse methods and advanced audit tools and techniques to perform different auditing tasks and tests effectively and efficiently (Bedard, Jackson, Ettredge, \& Johnstone, 2003; Braun \& Davis 2003; Curtis \& Payne, 2014; Dowling \& Leech 2007).

Different IT tools and techniques have been recommended in literature that can be used in auditing and may help auditors perform audit effectively and efficiently (Greenstein-Prosch, Mckee, \& Quick, 2008). However, as mentioned above, the most recommended type of IT that is encouraged by professionals and now advised by audit standards is CAATs. This type of IT tools and techniques is discussed next.

\subsection{Computerized Assisted Audit Techniques (CAATs)}

CAATs can be generally defined to represent any use of technology to assist in the completion of an audit (Braun \& Davis, 2003; Singleton, 2003). Yet, a more recent definition is to limit the use of the term to "various tools, technologies, and software that help auditors to conduct control and confirmation tests, analysis and verification of financial statement data, and continuous monitoring and auditing" (Lin \& Wang, 2011: 777). Regarding the aim of this paper and following previous studies' definitions, CAATs is defined as any use of technology to help auditor in the completion of an audit such as Electronic Spreadsheets, Electronic Working Papers, Test Data, Integrated Test Facility (ITF), Parallel Simulation, Embedded Audit Modules EAM/ System Control and Audit Review Files (/SCARF) and Generalized Audit Software (GAS). These seven types, their individual descriptions are shown in Table 1.

Table 1. Typology of CAATs, Adapted from (Braun \& Davis, 2003; Jaksic, 2009)

\begin{tabular}{|c|c|}
\hline $\begin{array}{l}\text { Types } \\
\text { CAATs }\end{array}$ & Description \\
\hline $\begin{array}{l}\text { Electronic } \\
\text { Spreadsheet }\end{array}$ & $\begin{array}{l}\text { Electronic Spreadsheet is a computer software application that is usually used for data classification, } \\
\text { analysis and storage. Spreadsheets developed as an electronic imitation of paper accounting and } \\
\text { auditing worksheets. }\end{array}$ \\
\hline $\begin{array}{l}\text { Electronic } \\
\text { Working } \\
\text { Papers }\end{array}$ & $\begin{array}{l}\text { Audit Electronic work papers are documents which accumulate and preserve all audit evidence } \\
\text { obtained during the audit process. They are used to support the audit work done and to provide } \\
\text { assurance that the audit was accomplished in conformity with the applicable auditing standards. }\end{array}$ \\
\hline Test Data & $\begin{array}{l}\text { Fictitious-prepared data by auditor, which will be processed by the audited systems. The evaluation } \\
\text { bases on a comparison between the results of the test data and the auditor's expectations. The } \\
\text { processing within the audited systems is a "black box". }\end{array}$ \\
\hline Integrated Test & Processing of Test Data in separated areas or modules within the audited system. The results of the \\
\hline
\end{tabular}




\section{Macrothink Institute"}

\begin{tabular}{|l|l|}
\hline Facility & internal system controls are visible for the auditor. \\
\hline $\begin{array}{l}\text { Parallel } \\
\text { Simulation }\end{array}$ & $\begin{array}{l}\text { Auditor-developed application, which is completely separated from the client's systems. The results } \\
\text { of processing real data are compared with the results of the client's systems. }\end{array}$ \\
\hline $\begin{array}{l}\text { Embedded } \\
\text { Audit Module }\end{array}$ & $\begin{array}{l}\text { Auditor-developed module which is implemented within a client's system. EAM evaluates real data } \\
\text { by predefined criteria while it is processed. Results of EAM evaluations can be written into a } \\
\text { SCARF, which is send to the auditors for further examination. }\end{array}$ \\
\hline $\begin{array}{l}\text { Generalized } \\
\text { Audit Software }\end{array}$ & $\begin{array}{l}\text { Auditor-developed and self-contained applications, which evaluate extracted real data and analyze } \\
\text { them, regarding predefined criteria. Specifically, the programs designed for auditors to facilitate and } \\
\text { automates testing of } 100 \% \text { of population, to focuses attention on specific risk areas or transactions } \\
\text { and to identify duplicate items. Two most of the popular GAS are Audit Command Language (ACL) } \\
\text { and Interactive Data Extraction and Analysis (IDEA) }\end{array}$ \\
\hline
\end{tabular}

\subsection{Preceding Research about CAATs Adoption and Use}

Since the 1980s, IT has been used in audit practices to improve effectiveness and efficiency (Fischer, 1996). While there has been several empirical studies on adoption and usage of IT found in literature, very little research has focused on its implementation and use in an audit context especially in CAATs area (Aidi \& Kent, 2013). The most notable researches in this area are, Braun and Davis (2003) who surveyed governmental auditors regarding their usage of ACL. Their results found that while auditors have shown a high attitude toward the potential benefits associated with ACL, they displayed a lower confidence in their technical abilities to use ACL. Debreceny, Lee, Neo, and Toh (2005) studied CAATs' use by internal and external auditors in financial service in Singapore. They found that auditors' use of CAATs wasn't the norm in their regular audit assignment, instead, it was only driven by special case investigations. In addition, more recent studies investigated auditors' intentions to use CAATs employing a modified UTAUT. Payne and Curtis (2010) surveyed a group of senior auditors and examine their replies to an assumed audit involvement to implement new audit software. Their results showed that performance expectancy, effort expectancy, and facilitating conditions are positively related to commit to adopt the audit software. Mahzan and Lymer (2008) applied the UTAUT to the internal audit setting in the UK and found that performance expectancy and facilitating conditions influence internal auditors' intention to adopt CAATs. Aidi and Kent (2013) investigated the utilization of GAS by external auditors in the UK, Their results suggest that the use of GAS among the external auditors in UK was very low. The high cost of the implementation, the demanding skills required, and the technical difficulty of using GAS were identified as the main obstacles for such low adoption. Finally, Bierstaker, Janvrin, and Lowe (2014) used the UTAUT to inspect factors possibly affecting a high profile auditors' usage of CAATs in the USA. Their results indicate that performance expectations, audit firm's facilitating infrastructure support the auditors' intention to use CAATs.

Within Jordanian context few studies have dealt specifically with usage of information technology in auditing. Thnaibat's (2003) study aimed to determine the extent to which the external auditors in Jordan utilize information technology in audit work, and the effect of information technology on the efficiency and effectiveness of the audit process. The study concluded that (to a limited extent) auditors in Jordan use information technology in different 
phases of the audit work. He argued that the use of information technology in the audit process would improve its efficiency and effectiveness. Khaddash and Siam (2003) studied the extent of Jordanian auditors' acceptance of using information technology in auditing process. The study showed that though the Jordanian auditors were aware of the need to use information technology in auditing, its use remained at an early stage. Khaddash and Siam (2003) recommended that awareness of the importance of using information technology in auditing should be enhanced, that the rewards of using information technology in auditing should be promoted, and that auditors should have to attend information technology training courses. Finally a survey of Jordanian audit firms by Al-Farah (2011) revealed that Jordanian's auditors do not use contemporary technology in a way consistent with their knowledge of it. Low audit fees, the small size of the local firms, lack of education and training programs to inculcate necessary IT auditing skills, and the high cost of CAAT technology, emerge as obstacles inhibiting the use of CAATs.

This study however, extends the previous studies within the Jordanian context and attempts to investigate what factors might affect Jordanian external auditors' intention to utilize and adopt CAATs in undertaking their audit activities from information systems' research perspective? Information systems researchers emphasized that technology cannot improve performance if it is not adopted and used and studying the factors that affect the intention to adopt and use technology is a must first step and in fact is an antecedent of actual usage (Venkatesh \& Davis, 2000; Venkatesh, Morris, Davis, \& Davis, 2003). Technology acceptance therefore, has received much attention from accounting scholars and the technology acceptance models employed in the IS literature provided a starting point for exploring the issue in accounting and auditing contexts (e.g., Bedard, Jackson, Ettredge, \& Johnstone, 2003; Bierstaker, Janvrin, \& Lowe, 2014; Walsh \& White 2000; West \& Davis, 2008). The following section presents the technology acceptance models employed in the IS literature and justify the use of UTAUT as a conceptual framework for this study.

\subsection{Technology Acceptance Models}

A review of Information Systems and Information Technology (IS/IT) adoption literature revealed many competing theoretical models that have contributed in predicting the adoption behavior such as: The Theory of Reasoned Action (TRA) (Ajzen \& Fishbein, 1980), the Diffusion of Innovation (DOI) (Moore \& Benbasat, 1991), Theory of Planned Behavior (TPB) (Ajzen 1991; Taylor \& Todd, 1995), the Technology Acceptance Model (TAM) (Davis, 1989), Social Cognitive Theory (Compeau \& Higgins, 1995), and the Unified Theory of Acceptance and Use of Technology (UTAUT) (Venkatesh, Morris, Davis, \& Davis, 2003). Each of these models has a specific focus and a particular set of adoption factors with some overlaps found between them (Dillon \& Morris 1996; Williams, Dwivedi, Lal, \& Schwarz, 2009).

However, one of the well-known models related to technology acceptance and the one that is used in this research is the UTAUT (Venkatesh, Morris, Davis, \& Davis, 2003). The rationale behind this choice is that UTAUT incorporates elements of several prominent of the previous eight information systems models/theories that predict IS/IT usage. Furthermore, Venkatesh, Morris, Davis, and Davis (2003, p. 437) and to ensure the robustness of their model, they 
apply it across various contexts. Their results have revealed that their model was valid, strongly supported and explained up to 70 percent of variance in intention to use technology, outperforming previous models (Venkatesh, Morris, Davis, \& Davis, 2003).

\section{Research Model and Hypothesis Development}

Building on the previous literature, and using UTAUT, in this section, the research proposes a conceptual model for factors may affect Jordanian external auditors' intention to adopt and use CAATs. The model and its constructs are depicted in Figure 1 followed by their definition and explaining the theoretical rationale for their inclusion.

UTAUT postulates that IT adoption and usage is affected by performance expectancy, effort expectancy, social influence, and facilitating conditions (Venkatesh, Morris, Davis, \& Davis, 2003).

\subsection{Performance Expectancy}

Performance expectancy refers to the extents to which an individual believes that using the tool can aid in attain gains in job performance (Venkatesh, Morris, Davis, \& Davis, 2003). According to (Jaksic, 2009) and (Saygili, 2010) auditors who believe that adoption of CAATs might enhance their audit productivity and the quality of audit work, should have positive intentions to adopt the technology. Banker, Hsihui, and Yi-Ching (2002) found that using CAATs in big audit firms reduces audit time needed for working paper preparation. They also found that the audit professionals' decision-making process was enhanced by electronic presentation of accounting information (Banker, Hsihui, \& Yi-Ching, 2002). Furthermore, auditors' belief that using CAATs will improve the efficiency of conducting audit tests of controls and substantive testing, are likely to have high intentions to adopt CAATs according to Bedard, Jackson, Ettredge, and Johnstone (2003) and Loraas and Wolfe (2006).

Withstanding these benefits, the researcher believes that Jordanian external auditors' perceptions of the usefulness and productivity they expect to gain from using CAATs in their auditing domain, will positively influence the intention to adopt and use them. Consequently, it is hypothesized that:

H1. Performance expectancy will influence positively Jordanian external auditor's intention to adopt and use CAATs.

\subsection{Effort Expectancy}

Effort expectancy refers to "the degree of ease associated with the use of the tool" (Venkatesh, Morris, Davis, \& Davis, 2003: 26). UTAUT advocates that perceived ease of use is expected to affect positively via effort expectancy the behavioral intention to use or adopt a tool (Venkatesh, Morris, Davis, \& Davis, 2003). Within audit perspective, the complexity and difficult use of CAATs might have negative influence to the adoption of new audit technology by auditors (Aidi \& Kent 2013). UTAUT suggest that there is a higher possibility that auditors particularly those with significant IT training, would utilize CAATs when they are easy to use and therefore, no difficult learning process is required to make use of them (Payne \& Curtis 2010). Bedard, Jackson, Ettredge, and Johnstone (2003) illustrates that the 


\section{Macrothink}

Business and Economic Research

ISSN 2162-4860 2016, Vol. 6, No. 1

perception of ease of use was very important among experienced auditors, thus hypothetically recommending the use of this construct in the modeling of technology acceptance by auditors. Therefore the research hypothesize that:

H2. Effort expectancy will influence positively Jordanian external auditor's intention to adopt and use CAATs.

\subsection{Social influence}

Social influence may be defined as "the degree to which an individual perceives that important others believe he or she should use the new tool" (Venkatesh, Morris, Davis, \& Davis, 2003: 27). In an audit setting, the extent to which auditors perceive that their managers' appreciation and indorsement of CAATs' usage may affect whether they adopt it or not. Loraas and Wolfe (2006) found that manager encouragement supports positively and affect behavioral intention. Therefore the research postulates that:

H3. Social influence will influence positively Jordanian external auditor's intention to adopt and use CAATs.

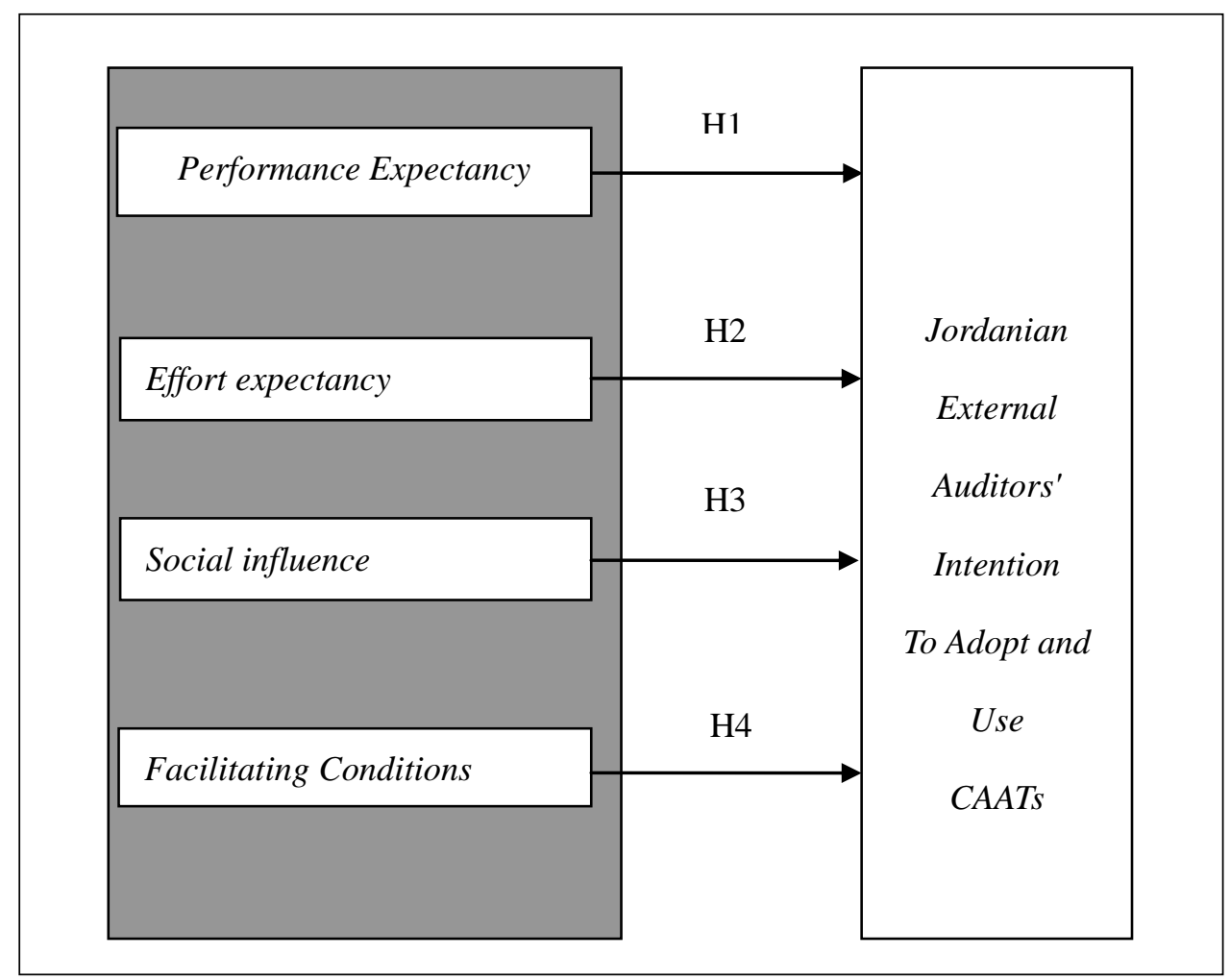

Figure 1. The Research Conceptual Framework

\subsection{Facilitating Conditions}

Facilitating conditions are defined as "The degree to which an individual believes that an organizational and technical infrastructure exists to support use of the system" (Venkatesh, Morris, Davis, \& Davis, 2003: 29). In an audit perspective, this may encompass audit firms offering proper CAATs resources, technical support and usage guidelines to their employees 
and sufficiency of information on what CAATs can do (CICA 1994; Dowling, 2009; Thompson, Higgins, \& Howell, 1991). Thus, it is hypothesized that:

H4. Facilitating conditions will influence positively Jordanian external auditor's intention to adopt and use CAATs.

\subsection{Behavioral Intention}

Behavioral Intention (BI) refers to "individual's intention to perform a behavior" (Ajzen, 1991). Ajzen (1991) indicated that BI is the most proximate predictor of behavior and is proposed to be an antecedent of actual usage. According to UTAUT intention to adopt and use CAATs is the dependent variable in the research model and is a function of performance expectancy, effort expectancy, social influence and facilitating conditions (Venkatesh \& Davis, 2000; Venkatesh, Morris, Davis, \& Davis, 2003). This construct puts the original 'intention to use' construct in the CAATs' setting.

\section{Research Methodology}

The objective of this study was to extend of UTAUT within public accounting domain. Hence, efforts were made to keep the research method very similar to that used by earlier studies on UTAUT, to maintain the continuity of the research agenda. The study hence, used instruments developed by Mahzan and Lymer (2008), Venkatesh, Morris, Davis, and Davis (2003) and Janvrin, Bierstaker, and Lowe (2009). However, the questions that were selected from their validated questionnaires were modified to the practice of CAATs context. The structure and the validation procedures for the survey are discussed next.

\subsection{The Research Instrument Development and Validation}

As mentioned above, the study has drawn upon qualified questionnaires to gather the data from audit firms. The questionnaire consisted of three sections which starts with a brief description of the meaning of the main concepts and it gives the instructions on how to answer each section of the questionnaire. The second section contained basic demographic characteristics including gender, age, measures for assessing the level of IT usage and CAATs experience (perception relative to the usage of CAATs), etc. In the third section, the survey participants were asked to respond to questions on the five constructs of the model: performance expectancy, effort expectancy, social influence, facilitating conditions and behavioral Intention. For each construct, a five-point Likert scale, ranging from strongly disagree (1) to strongly agree (5), was used. The survey was originally written in English. However, as the survey has to be conducted in a non-English-speaking country, it was translated into Arabic. Translation of all terms has been completed at most accurate way possible so as to allow researcher to use comparatively the results of this survey with results obtained from other similar CAATs surveys.

To ensure the reliability and validity of the translated questionnaire, several criteria have been considered prior to administering it (Cook \& Campbell, 1979; Shadish, Cook, \& Campbell, 2002). The questionnaire was subject to a pre-test by a small sample (10 respondents) 5 academics in audit and accounting information systems and 5 practicing auditors to improve 
the clarity of both questionnaire's instructions and questions (Oppenheim, 2001). This procedure helps to give the best feedback about the construct and the content of the questionnaire.

Table 2. Reliability Results

\begin{tabular}{|l|c|c|l|}
\hline Model Constructs & $\begin{array}{l}\text { Number of } \\
\text { Questions }\end{array}$ & Cronbach's Alpha & Result \\
\hline Performance Expectancy & 6 & 0.912 & accepted \\
\hline Effort Expectancy & 4 & 0.801 & accepted \\
\hline Social Influence & 4 & 0.824 & accepted \\
\hline Facilitating Conditions & 3 & 0.901 & accepted \\
\hline Behavioral Intention & 3 & 0.850 & \\
\hline
\end{tabular}

In addition, after data collection the construct was subjected to the scale reliability procedure using the Cronbach's Alpha criterion to assess the internal consistency and reliability of the studied construct (Sekaran \& Bougie, 2010). In this study, reliability was tested on five parts of the questionnaire's constructs, namely Performance Expectancy, Effort Expectancy, Social Influence, Facilitating Conditions and Behavioral Intention. Table 2 presents the reliability test results. The Cronbach' Alpha coefficient is above 0.80, the value exceeds the accepted cut-off value of 0.70 , as suggested by (Nunnally, 1978). This indicates that each individual item is internally consistent and highly reliable.

\subsection{Participants and Data Collection Procedure}

The target population of this study was all statutory audit practitioners registered in the Jordanian Association of Certified Public Accountants (JACPA) as of January $1^{\text {st }} 2015$. However, the accessible population was all auditors in national, and Big 4 firms in Amman (The majority of the Jordanian audit firms are located in Amman). Simple random sampling technique was used to arrive at the sample of the study. The sample size of 200 audit practitioners out of 384 statutory auditors for the study was drawn. The data collection was conducted using questionnaires (see the previous section) that were self-administered by hand and mailed to the selected study sample. The response rate was 80.5 percent (a total of 161 questionnaires after the follow-up activities were returned for statistical analysis). Data entry, descriptive and analytical analysis for the questionnaire were conducted using Statistical Package for the Social Sciences (IBM SPSS 22.0). The following sections discuss the data analysis and findings of the study and addresses the research hypothesis.

\section{Data Analysis and Results Discussion}

\subsection{Demographic Statistics of the Respondents}




\section{Macrothink}

Business and Economic Research

ISSN 2162-4860

2016, Vol. 6, No. 1

Table 3 below shows the demographic statistics summaries as extracted from the distributed questionnaires. The demographic information highlight the important characteristics of the respondents and may be useful to correlate with other survey findings. The sample is comprised of 156 (97\%) males and 5 females (3\%). These data reflect that the auditing profession in Jordan is occupied mainly by males. This is somehow reflect the culture and the norm in Jordan despite its contrast with another world contexts where accounting and auditing are perceived to be trending towards being a female dominated profession (e. g., Bierstaker, Janvrin, \& Lowe, 2014).

In contrast with the gender distribution above, the respondent are shown to be relatively young practitioners. The table indicates that external auditors are almost young people were the ages of $125(77.36 \%)$ are under the age of 40 .

Table 3. Participant Demographics

\begin{tabular}{|c|c|c|c|c|}
\hline Sample Characteristics & Contents & Frequencies & percent & $\begin{array}{l}\text { Cumulative } \\
\text { Percent }\end{array}$ \\
\hline Gender & $\begin{array}{l}\text { Male } \\
\text { Female }\end{array}$ & $\begin{array}{c}156 \\
5\end{array}$ & $\begin{array}{c}97 \\
3\end{array}$ & $\begin{array}{c}97 \\
100\end{array}$ \\
\hline Age & $\begin{array}{l}25-30 \\
31-35 \\
36-40 \\
41-50 \\
51+\end{array}$ & $\begin{array}{l}11 \\
24 \\
90 \\
30 \\
6\end{array}$ & $\begin{array}{c}6.83 \\
14.90 \\
55.90 \\
18.63 \\
3.74\end{array}$ & $\begin{array}{c}6.83 \\
21.73 \\
77.63 \\
96.26 \\
100\end{array}$ \\
\hline Highest education level & $\begin{array}{l}\text { Diploma } \\
\text { Bachelor's degree } \\
\text { Master's degree } \\
\text { Coursework beyond } \\
\text { master's degree }\end{array}$ & $\begin{array}{c}0 \\
141 \\
14\end{array}$ & $\begin{array}{c}0 \\
87.60 \\
8.7\end{array}$ & $\begin{array}{c}0 \\
87.60 \\
96.3 \\
\end{array}$ \\
\hline Professional Certification (a). & $\begin{array}{l}\text { JCPA } \\
\text { ACPA } \\
\text { CPA }\end{array}$ & $\begin{array}{l}100 \\
18 \\
22\end{array}$ & $\begin{array}{l}62.11 \\
11.18 \\
13.66\end{array}$ & $\begin{array}{l}62.11 \\
73.29 \\
86.95\end{array}$ \\
\hline
\end{tabular}




\begin{tabular}{|c|c|c|c|c|}
\hline & $\begin{array}{l}\text { CMA } \\
\text { Other certification }\end{array}$ & $\begin{array}{l}20 \\
1\end{array}$ & $\begin{array}{l}12.43 \\
0.62\end{array}$ & $\begin{array}{r}99.38 \\
100\end{array}$ \\
\hline Years as an external auditor & $\begin{array}{l}1-4 \\
5-9 \\
10+\end{array}$ & $\begin{array}{c}7 \\
30 \\
124\end{array}$ & $\begin{array}{r}4.34 \\
18.64 \\
77.02\end{array}$ & $\begin{array}{c}4.34 \\
22.98 \\
100\end{array}$ \\
\hline IT expertise & $\begin{array}{l}\text { Novice } \\
\text { Intermediate } \\
\text { Expert }\end{array}$ & $\begin{array}{l}30 \\
117 \\
14\end{array}$ & $\begin{array}{l}18.63 \\
72.67 \\
8.70\end{array}$ & $\begin{array}{c}18.63 \\
91.30 \\
100\end{array}$ \\
\hline $\begin{array}{l}\text { To what extent are you using } \\
\text { computer-assisted } \\
\text { audit techniques (CAATs) }\end{array}$ & $\begin{array}{l}\text { to a small extent }=1 \\
\text { to some extent }=2 \\
\text { to a moderate extent }=3 \\
\text { to a great extent }=4 \\
\text { to a very great extent }=5 \\
\text { Mean: } \\
\text { Std. Dev. }\end{array}$ & $\begin{array}{c}10 \\
107 \\
30 \\
8 \\
6 \\
2.06 \\
1.23\end{array}$ & $\begin{array}{c}6.21 \\
66.46 \\
18.63 \\
4.97 \\
3.73\end{array}$ & $\begin{array}{c}6.21 \\
72.67 \\
91.30 \\
96.27 \\
100\end{array}$ \\
\hline
\end{tabular}

Furthermore the table shows that $(87.6 \%)$ of the respondents have bachelor degrees, followed by nearly $(8.7 \%)$ of the respondents have a master degree. Also the table indicates that $(99.38 \%)$ of the respondents have professional certificate. This is essentially representing the norm in the profession where holding local or global professional certificate is recommended by professional bodies in Jordan. However, the local professional certificate, Jordanian Certified Public Accountant (JCPA) compromises (62.11\%). This is in fact due to the new initiation of the only professional certificate in Jordan JCPA in 2003 which makes the certificate becomes more prevalent.

The table further reveals that $124(77.01 \%)$ of the external auditors with more than 10 years of experience. Thus, it anticipated that the auditors' experience would be adequate to facilitate the essential collaboration to have their clients' data in a state fit for the use of contemporary auditing techniques. In addition, the table shows that 127 (72.67\%) of the auditors have intermediate level of IT experience. It is hence, reasonably to expect that those auditors are familiar with latest audit technology and accordingly press for professional engagement of them in their different audit contexts.

Finally the table depicts that the majority of the respondents 107 (66.46\%) were using CAATs to some extent. For this question the auditors had to choose between: to a small extent $=1$; to some extent $=2$; to a moderate extent $=3$; to a great extent $=4$; or to a very great extent $=5$. 


\section{Macrothink}

Business and Economic Research

ISSN 2162-4860

2016, Vol. 6, No. 1

The mean rating for this question (2.06) suggesting that, on average, Jordanian external auditors use CAATs most frequently to some extent.

This result represents the current status of CAATs utilization by external auditors in Jordan? The result indicated the fact that CAATs' usage in Jordan are still at its early stage despite the auditors' long experience and their moderate IT literacy. The result is consistent with and confirms prior research from the Jordanian setting (e.g., Al-Farah, 2011; Khaddash \& Siam 3003; Thnaibat's, 2003) as well as with results from different world's contexts (e.g., Aidi \& Kent 2013; Arnold \& Sutton, 1998; Bierstaker, Janvrin, \& Lowe, 2014; Curtis \& Payne, 2010; Debreceny, Lee, Neo, \& Toh, 2005; Janvrin, Bierstaker, \& Lowe, 2009; Kalaba 2002; Kotb \& Roberts, 2011; Liang, Lin, \& Wu, 2001; Rowe, 2008). However, it is the intention of this research to extend the previous research from the Jordanian setting and to find out the factors that might affect such a low adoption rate of CAATs. This issue is discussed next.

\subsection{Factors Affecting CAATs Adoption in Jordan}

This section of the study presents the results and discussions of the third part of the survey and answer the research question. Table 4 below, shows the descriptive statistics for measuring constructs items and presents a summary of responses received from respondents for each factors that provided as the drives for CAATs' adoption.

Table 4. Survey Result

\begin{tabular}{|c|c|c|c|c|}
\hline Predictor variable & Min. & Max. & Mean & $\begin{array}{l}\text { Std. } \\
\text { Dev. }\end{array}$ \\
\hline Performance Expectancy & & & & \\
\hline PE1 I find (CAATs) a useful tool in my work. & 4 & 5 & 4.26 & 1.98 \\
\hline PE2 CAATs' usage permits me to complete audit jobs more quickly. & 3 & 5 & 4.83 & 1.03 \\
\hline PE3 CAATs' usage enhances my audit work's productivity. & 4 & 5 & 4.82 & 1.99 \\
\hline PE4 CAATs' usage will increase my likelihoods of getting a raise. & 3 & 4 & 3.80 & 1.07 \\
\hline $\begin{array}{l}\text { PE5 CAATs' usage will enable me to spend less time on the routine tasks of } \\
\text { audit }\end{array}$ & 4 & 5 & 4.16 & 1.99 \\
\hline PE6 CAATs' usage improves the quality of the auditing work I do & 4 & 5 & 4.88 & 1.82 \\
\hline Average performance expectancy & & & 4.62 & 1.34 \\
\hline
\end{tabular}


Effort Expectancy

EE1 I find my engagement with CAATs clear and understandable.

EE2 Attaining skills to use CAATs is easy for me.

EE3 CAATs are easy to use tools for me.

EE4 Learning how to operate CAATs is an easy process for me.

Average effort expectancy

Social Influence

SI1 Individuals who inspire my behavior think that I should use CAATs.

SI2 Persons who are significant to me believe that I should use CAATs.

SI3 My firm senior managers have been cooperative in the use of CAATs.

SI4 Overall, my firm has supported the use of CAATs.

Average social influence

Facilitating Conditions

FC1 The resources necessary to use CAATs are available for me.

FC2 I have the sufficient knowledge necessary to use CAATs.

FC3 Assistance with CAATs' difficulties is always available for me by a technical person or by group.

Average facilitating conditions

Behavioral Intention to Utilize

BI1 I intend to use CAATs in the foreseeable future.

BI2 I predict I would use CAATs in the coming future.

BI3 My use of CAATs is very likely to occur soon.

Average Behavioral Intention to Utilize 
From the descriptive statistics table 4 above, the performance expectancy indicated a very high mean rate of $\mathbf{4 . 6 2}$ which shows that usefulness and rewards factors are significant and play a major role in the intention to use and adopt CAATs by Jordanian external auditors. In addition, facilitating conditions' high mean rate of $\mathbf{4 . 1 7}$ indicates that availability of resources and organizational infrastructure within the Jordanian audit firms can enhance external auditors' audit work and hence, plays also a main role in the intention of CAATs' usage and adoption. However, the lower mean rates for effort expectancy (2.67) and social influence (2.92) indicate that these factors may not play such a major role as compared to other constructs factors. The comments on these results and their supportive literature will be presented along with hypotheses analyses in the next section.

\subsection{Hypotheses Analyses}

This section comes to further enhance the results in previous section, to test the research hypotheses and to find out if there is any association between the UTAUT construct, performance expectancy, effort expectancy, social influence, and facilitating conditions as the predictor variables and the Jordanian external auditors' intention of CAATs' usage and adoption as the dependent variable. Multiple regression analysis was used to validate the research model and to test the research hypotheses. To determine the relationships among the variables, $\boldsymbol{\beta}, \mathbf{t}$ and $\operatorname{Sig}(\mathbf{p})$ values are very important indication of the impact of each predictor variable for explaining the dependent variable. A big absolute $\mathbf{t}$ value $>3$, ( 3 was selected to be the cut-off point of the likert scale mean, representing the hypothesized population mean (Cavana, Delahaye, \& Sekaran, 2001: 426)), and small p value $<0.05$, suggests that a predictor variable is having a significant impact on the dependent variable (Hair, Black, Babin, Anderson, \& Tatham, 2005).

The multiple regression analysis was directed by the following linear model:

$T I A U=\beta 0+\beta 1 P E+\beta 2 E E+\beta 3 F C+\beta 4 S I+\varepsilon$

where,

$$
\begin{array}{ll}
\text { TIU } & =\text { Total Intention to CAATs' Adoption and Usage } \\
\text { PE } & =\text { Performance expectancy } \\
\mathrm{EE} & =\text { Effort expectancy } \\
\text { FC } & =\text { Facilitating conditions } \\
\text { SI } \quad=\text { Social influence } & \\
\beta 0-\beta 4=\text { Coefficients } & \\
\varepsilon=\text { Error term }
\end{array}
$$

Table 5 below presents the results of hypothesis test by using the regression analysis. 
Table 5. Results of Regression Analysis.

\begin{tabular}{|l|c|c|c|c|l|l|}
\hline Variables & Hypotheses & Coef. & $\beta$ & $\mathrm{t}$-Stat & Sig (0.05) & \\
\hline 1) Statistics for individual factors & & & & & & \\
\hline Intercept & & $\beta 0$ & -0.10 & & & \\
\hline Performance expectancy (PE) & $H 01$ & $\beta 1$ & 0.142 & 4.5 & 0.03 & Supported \\
\hline Effort expectancy (EE) & $H 02$ & $\beta 2$ & -0.087 & -1.6 & 0.091 & Not supported \\
\hline Social influence (SI) & $H 03$ & $\beta 3$ & 0.025 & 2.6 & 0.076 & Not Supported \\
\hline Facilitating conditions (FC) & $H 04$ & $\beta 4$ & 0.321 & 3.5 & 0.00 & Supported \\
\hline 2) Overall model statistics & & & & & & \\
\hline F-value & & & & 25.67 & & \\
\hline Overall model p-value & & & & 0.001 & & \\
\hline Adjusted R (\%) & & & & & & \\
\hline
\end{tabular}

The following inferences can be made from the regression outputs. The model has statistically significant overall F-values 25.67 , p-value $<0.005$ (i.e., the overall regression model is a good fit for the data) and substantial amount of variance (adjusted $\mathrm{R}^{2}$ of $45 \%$ ) is explained by the model.

$H_{1}$, which establishes the link between performance expectancy and intention to use CAATs, is strongly supported ((b: 0.142, t: 4.5, sig: 0.03). This implies that Jordanian external auditor perceive a higher level of performance expectancy from CAATs' adoption and usage and hence, the intention to use CAATs in auditing is expected to be high.

$\mathrm{H}_{4}$, which posits the relationship between facilitating conditions and the intention of using CAATs, is also supported (b: .321, t: 3.5 sig: 0:000). This implies that if auditing companies in Jordan provide the necessary resources and infrastructure, required knowledge and assistance, Jordanian external auditors' intention to use CAATs is expected to be high. These results are consistent with results from previous section and confirm the results of the studies conducted by Bierstaker, Janvrin, and Lowe (2014), Janvrin, Bierstaker, and Lowe (2009), Mahzan and Lymer (2008) which stated that performance expectancy and facilitating conditions are major factors in auditors' intention to accept and use CAATs. In addition, the result is consistent with Thnaibat's (2003) study who argued that the use of information technology in the audit process would improve its efficiency and effectiveness. 
However, $\mathrm{H}_{2}$, which addresses perceived ease of use and posits a positive relationship between effort expectancy and intention to use CAATs is not supported (b: -0.087 , t: -1.6 , sig: 0:091) hence, we accept the alternative hypotheses. This implies that the Jordanian external auditor perceive that using CAATs is not easy and thus, the intention to CAATs' usage and adoption will not correspondingly be high. Therefore, there is a higher possibility that Jordanian external auditors would adopt CAATs when they are easy to use and no difficult learning process is required to make use of them. One possible explanation regarding the lower mean rates for effort expectancy and the non supporting results for relationship between effort expectancy and intention to use CAATs is that, the exposure to CAATs in Jordan is still at its early stage and the types of applications are limited to auditors with a high CAATs' expertise. Inadequate knowledge of CAATs and its applications might lower the intention to use it by auditors with no previous experience. These results are consistent with study of Aidi and Kent (2013) which indicated that technical difficulty and demanding knowledge required to use CAATs are one of the main obstacles that justify their low adoption and use in UK. The result is additionally consistent with study of Al-Farah (2011) which revealed that lack of education and training programs to inculcate necessary IT auditing skills among Jordanian's auditors emerges as obstacles inhibiting their use of CAATs.

$\mathrm{H}_{3}$, which establishes the relationship between social influence and intention to use CAATs, is also not supported (b: 0.025, t: 2.6, sig: 0.076). This implies that the Jordanian external auditor perceive that social encouragement is not a vital factor in their intention to use and adopt CAATs. This result is in contradiction with the result of Loraas and Wolfe (2006) who found that manager encouragement and peers support positively influences behavioral intention and present another perspective within the Jordanian auditing practice.

\section{Conclusion, Recommendations and Limitations}

Despite the emerging and accelerated ICT initiatives and efforts of auditing professional bodies to help progression the implementation of audit technologies among audit organizations, and given the appealed benefits of CAATs in increasing audit effectiveness and efficiency (Dowling, 2009; Dowling \& Leech, 2007), to date CAATs have been used to a limited extent and their usage by Jordanian external auditors and alongside the world's trend are not yet widely widespread (Al-Farah 2011; Curtis \& Payne, 2008; Debreceny, Lee, Neo, \& Toh, 2005; Kalaba, 2002; Khaddash \& Siam, 2003; Liang, Lin, \& Wu, 2001; Rowe, 2008 ; Thnaibat's 2003).

This study explored this lack of pervasive use of CAATs in Jordan and tried to find answers to what factors may affect their adoption and use. The research surveyed the Jordanian external auditors about the factors may affect their use of CAATs technology in auditing practice using the unified theory of acceptance and use of technology (UTAUT), a wellknown theory in IT research (Venkatesh, Morris, Davis, \& Davis, 2003). Through the application of a modified model of UTAUT framework and with data obtained from 161 Jordanian auditors representing Big 4, and national audit firms and with statistical testing of these data, the results indicated that the significant factors leading Jordanian external auditors' 
intentions to use of CAATs technology are performance expectancy and facilitating conditions.

These results suggest that these two key drivers may increase the possibility that Jordanian external auditors will use CAATs as respondents assigned higher mean ratings to performance expectancy (4.62) and facilitating conditions (4.17) than to effort expectancy (2.67) and social influence (2.92). The results from hypotheses testing further confirmed these results. It's found that performance expectancy and facilitating conditions are significant at the p-value 0.05 and the empirical testing of the proposed model found the model to be strongly supported and is statistically significant with overall F-values 25.67, overall model p-value 0.001 and adjusted $\mathrm{R}^{2}$ of $45 \%$.

These findings have different implications. First, audit firms may developing and actively promoting training programs to increase auditors' knowledge and skills to make it easy to learn and to operate CAATs and by doing so improve auditors' performance expectancy and consequently increase CAAT usage. In the context of this research, these programs may be particularly useful since the research participants on average, assigned low importance ratings to CAATs' ease of use and the hypothesis regarding effort expectancy wasn't also supported. Furthermore, results may inspire audit firms to further invest in adequate infrastructure supporting CAATs. Finally, audit firms might encourage CAATs usage through incentives and promotion criteria mainly for auditors that are less motivated to adopt CAATs.

The research however, has certain limitations. First, data was collected by asking the auditors to ascertain the extent of their CAATs' usage based on their perception. A better proxy that could increase model validity, might be using actual data collected by observing their real CAATs' usage (Devaraj \& Kohli, 2003; Straub, Limayem, \& Karahanna, 1995; Venkatesh, Morris, Davis, \& Davis, 2003). Second, the sample data was collected randomly in a homogeneous way without segregation between Big 4 and local audit firms. As Big 4 firms usually perform audit to larger clients who have more complex IT and thus drive CAATs' usage, a more advanced studies could be carried out to identify if different results might be revealed when such sampling distinction take place. Third, although empirical evidence shows that the research model may explain and provide interesting insights into the factors affecting the auditor's intention toward CAATs' adoption; yet, it does not fully explain auditor's behavior and intention. One possible explanation for that could be some other factors need to be considered to determine and to fully understand the low adoption rate of CAATs by Jordanian external auditors, (e.g., cost of technology, lack of client cooperation, education and training programs, and size of audit firm). Finally, the research was examined based on a sample of external auditors however, the sample may not be fully representative of the entire population and thus a sample selection bias might occurs. Future research may choose more samples of external auditors in order to get a better view. In addition, future research may also collect data via interviews of senior auditors and use date triangulation techniques to validate the results obtained by this research.

Despite the above mentioned limitations, audit companies can create a positive attitude amongst its auditors towards CAATs' usage and adoption by promoting CAATs' benefits and 
usefulness, by decreasing efforts expectancy needed to use CAATs, and by further investing in organizational and technical infrastructure supporting CAATs and by doing so, overcome the obstacles and challenges facing the development of auditing profession in Jordan.

\section{References}

Aidi, A., \& Kent, S. (2013). The utilisation of generalized audit software (GAS) by external auditors. Managerial Auditing Journal, $28, \quad 88-113$. http://dx.doi.org/10.1108/02686901311284522

Ajzen, I. (1991). The Theory of Planned Behavior. Organizational Behavior and Human Decision Processes, 50, 179-211.http://dx.doi.org/10.1016/0749-5978 (91)90020

Ajzen, I., \& Fishbein, M. (1980). Understanding attitudes and predicting social behavior. Englewood Cliffs, NJ: Prentice-Hall.

Al-Farah, A. (2011). Audit Technology Gap in Developing Countries - the Jordanian CPA Firms: Towards enhancing the corporate governance credibility in developing countries, the case of Jordan. Germany: VDM Publishing.

Al- Farah,A., Abbadi,S., \& AL Shaar, E. (2015). The Accounting and Auditing Profession in Jordan: Its Origin and Development. Developing Country Studies, 5, 167-179.

Al-Shboul, M., \& Alsmadi. I. (2010). Jordan E-Government Challenges and Progresses. International Journal of Advanced Cooperating Learning iJAC, 3, 37-41.

American Institute of Certified Public Accountants (AICPA). 2001. The Effect of Information Technology on the Auditor's Consideration of Internal Control in a Financial Statement Audit. Statement of Auditing Standards No. 94. New York NY: AICPA.

American Institute of Certified Public Accountants (AICPA) (2002a). Consideration of fraud in financial statement audit. Statement of auditing standard no. 99. New York, NY: AICPA.

American Institute of Certified Public Accountants (AICPA) (2002b). Interim financial information. Statement of auditing standard no. 100. New York, NY: AICPA.

American Institute of Certified Public Accountants (AICPA) (2002c). Audit documentation. Statement of auditing standard no. 96. New York, NY: AICPA.

American Institute of Certified Public Accountants (AICPA) (2006). Audit Risk Exposure Standards. Statements of Auditing Standards New York NY: AICPA.

Arens, A. A., Elder, R. J., \& Beasley, M. S. (2014). Auditing and assurance services: An integrated approach. Upper Saddle River, N.J: Prentice Hall.

Banker, R. D., Hsihui, C. \& Yi-Ching, K. (2002). Impact of Information Technology on Public Accounting Firm Productivity. Journal of Information Systems, 16, 209-222. http://dx.doi.org/10.2308/jis.2002.16.2.209

Bedard, J., Jackson, C., Ettredge, M. L., \& Johnstone, K. M. (2003). The effect of training on auditors' acceptance of an electronic work system. International Journal of Accounting 
Information Systems, 4, 227-250. http://dx.doi.org/10.1016/j.accinf.2003.05.001

Bierstaker, J., Burnaby, P., \& Thibodeau, J. (2001). "The impact of Information technology on the audit process: an assessment of the state of the art and implications for the future" Managerial Auditing Journal, 16, 159-164. http://dx.doi.org/10.1108/02686900110385489

Bierstaker, J., Janvrin, D., D., \& Lowe, J. (2014). What factors influence auditors' use of computer-assisted audit techniques?. Advances in Accounting, 30, 67-74. http://dx.doi.org/10.1016/j.adiac.2013.12.005

Braun, R. L., \& Davis, H. E. (2003). Computer-assisted audit tools and techniques: Analysis and perspectives. Managerial Auditing Journal, 18, 725-731. http://dx.doi.org/10.1108/02686900310500488

Cavana, R., Delahaye, B., \& Sekaran, U. (2001). Applied Business Research: Qualitative and Quantitative Methods. Australia: John Wiley \& Sons, Ltd.

CICA, (1994). The Application of CAATTS using Microcomputers Research Report. The Canadian Institute of Chartered Accountants, Toronto, Ontario.

Compeau, D.R., \& Higgins, C.A. (1995). Computer self-efficacy: Development of a measure and initial test. MIS Quarterly, 19, 189-212. http://dx.doi.org/10.2307/249688

Cook, T. D., \& Campbell, D. T. (1979). Quasi-Experimentation: Design and Analysis Issues for Field Settings. Chicago: Rand McNally.

Curtis, M. B., \& Payne, E. A. (2008). An examination of contextual factors and individual characteristics affecting technology implementation decisions in auditing. International Journal of Accounting Information Systems, 9, 104-121. http://dx.doi.org/ 10.1016/j.accinf.2007.10.002

Curtis, M. B., \& Payne, E. A. (2014). "Modeling voluntary CAAT utilization decisions in auditing". Managerial Auditing Journal, $29, \quad 304-326$. http://dx.doi.org/10.1108/MAJ-07-2013-0903

Davis, F. D. (1989). 'Perceived Usefulness, Perceived Ease of Use and User Acceptance of Information Technology'. MIS Quarterly, 13, 319-340. http://dx.doi.org/10.2307/249008

Debreceny, R., Lee, S., Neo, W., \& Toh, J. S. (2005). Employing generalized audit software in the financial services sector: Challenges and opportunities. Managerial Auditing Journal, 20, 605-619. http://dx.doi.org/10.1108/02686900510606092

Devaraj, S., \& Kohli, R. (2003). Performance impacts of information technology: Is actual usage the missing link? Management Science, 49, 273-289. http://dx.doi.org/10.1287/mnsc.49.3.273.12736

Dillon, A., \& Morris, M. G. (1996). User acceptance of information technology: Theories and models. Annual Review of Information Science and Technology (ARIST), 31, 3-32.

Dowling, C., \& Leech, S. (2007). Audit support systems and decision aids: Current practice 
and opportunities for future research. International Journal of Accounting Information Systems, 8, 92-116. http://dx.doi.org/10.1016/j.accinf.2007.04.001

Dowling, C. (2009). Appropriate audit support system use: The influence of auditor, audit team, and firm factors. The Accounting Review, 84, 771-810. http://dx.doi.org/10.2308/accr.2009.84.3.771

Foneca, B. (2003). Cyber security gets auditing push. Private sector targeted. Infoworld, 15 April.

Grand, C.L., (2001) Use of Computer-Assisted Audit Tools and Technique (CAATTs) Part 1, IT Audit, Vol. 4, October 1, The Institute of Internal Auditor.

Grand, C.L., (2001) Use of Computer-Assisted Audit Tools and Technique (CAATTs) Part 2, IT Audit, Vol. 4, October 15, The Institute of Internal Auditor.

Greenstein-Prosch, M., Mckee, T. E. \& Quick, R. (2008). A comparison of the information technology knowledge of United States and German auditors. The International journal of digital accounting research, 8, 45-79. http://dx.doi.org/10.4192/1577-8517-v8_3

Hair, J. F., Black, W., Babin, B., Anderson, R. E., \& Tatham, R. L. (2005). Multivariate data analysis. Upper Saddle River, NJ: Prentice Hall.

Hall, J. A. (2016). Information Technology Auditing. Mason, OH: Cengage Learning.

International Federation of Accountants [IFAC], (2009) International Education Practice Statement 2: Information Technology for Professional Accountants.

Jaksic, D., 2009. Implementation of computer assisted audit techniques in application controls testing. Management Information Systems, 4, 9-12.

Janvrin, D., Bierstaker, J., \& Lowe, D. J. (2009). An investigation of factors influencing the use of computer-related audit procedures. Journal of Information Systems, 23, 97-118. http://dx.doi.org/10.2308/acch.2008.22.1.1

Jordanian Association of Certified Public Accountants (JACPA). (2015) [Online] Available: http://jacpa.org.jo/ar-jo/home.aspx (January 1, 2015)

Kalaba, L. A. (2002). The benefits of CAAT. IT Audit, 5.

Khaddash, H. \& Siam, W. (2003). "The Extent of Auditors' Acceptance to the Use of Information Technology in Auditing”, Derassat, Business Administration, University of Jordan, 30, 279-290. (in Arabic).

Khemakhe, J. (2001). "Integral auditing”, International Journal of Government Auditing, 28, 6-9.

Laudon, K. C., \& Laudon, J. P. (2016). Management Information Systems: Managing the Digital Firm. Upper Saddle River, N.J: Prentice Hall.

Liang, D., Lin, F., \&Wu, S. (2001). Electronically auditing EDP systems with the support of 
emerging information technologies. International Journal of Accounting Information Systems, 2, 130-147. http://dx.doi.org/10.1016/S1467-0895(01)00014-8

Lin, C., \& Wang, C. (2011). A selection model for auditing software. Industrial Management and Data Systems, 111, 776-790. http://dx.doi.org/10.1108/02635571111137304

Loraas, T., \& Wolfe, C. J. (2006). Why wait? Modeling factors that influence the decision of when to learn a new use of technology. Journal of Information Systems, 20, 1-23. http://dx.doi.org/10.2308/jis.2006.20.2.1

Mahzan, N., \& Lymer, A. (2008). Adoption of computer assisted audit tools and techniques (CAATs) by internal auditors: Current issues in the UK. Proceedings of the British Accounting Association Annual Conference, Blackpool, UK.

Mahzan, N., \& Lymer, A. (2014). Examining the adoption of computer-assisted audit tools and techniques: Cases of generalized audit software use by internal auditors. Managerial Auditing Journal, 29, 327-349. http://dx.doi.org/10.1108/MAJ-05-2013-0877

Moore, G. C., \& Benbasat, I. (1991). Development of an Instrument to Measure the Perceptions of Adopting an Information Technology Innovation. Information Systems Research, 2, 192-222. http://dx.doi.org/10.1287/isre.2.3.192

Nunnaly, J. (1978). Psychometric theory. New York: McGraw Hill.

Oppenheim, A.N. (2001). Questionnaire Design, Interviewing and Attitude Measurement. Printer Publisher, London.

Payne, E. A., \& Curtis, M. B. (2010). Can the unified theory of acceptance and use of technology help us understand the adoption of computer-aided audit techniques by auditors? Working paper: University of Louisville and University of North Texas.

Public Company Accounting Oversight Board (PCAOB) (2007). An audit of internal control over financial reporting that is integrated with an audit of financial statements. Auditing standard no. 5. Washington D.C: PCAOB.

Public Company Accounting Oversight Board (PCAOB) (2010a). The auditor's response to the risks of material misstatement. Auditing standard no. 13. Washington D.C: PCAOB.

Public Company Accounting Oversight Board (PCAOB) (2010b). Evaluating audit results. Auditing standard no. 14. Washington D.C: PCAOB.

Rezaee, Z., \& Reinstein, A. (1998). "The impact of emerging information technology on auditing". Managerial Auditing Journal, 13,465 - 471. http://dx.doi.org/10.1108/02686909810236271

Romney, M. B., \& Steinbart, P. J. (2015). Accounting Information Systems. Upper Saddle River, NJ: Prentice-Hall.

Rosli, K., Yeow, P., \& Siew, E.-G. (2012). Factors Influencing Audit Technology Acceptance by Audit Firms: A New I-TOE Adoption Framework. Journal of Accounting and Auditing: 
Research \& Practice, 1-11. http://dx.doi.org/10.5171/2012.876814

Saygili, A.T. (2010). Taking advantage of CAATTs during testing phase in financial audits: An empirical study of a food processing company in Turkey. Global J. Manage. Bus. Res., 10, 113-119.

Sekaran, U. \& Bougie, R. (2010). Research methods for business: A skill building approach. Chichester: John Willey \& Sons Ltd.

Shadish, W. R., Cook, T. D., \& Campbell, D. T. (2002). Experimental and quasi-experimental designs for generalized causal inference. Boston: Houghton Mifflin.

Shaikh, J. M. (2005). E-commerce impact: Emerging technology-Electronic auditing. Managerial Auditing Journal, 20, 408-421. http://dx.doi.org/10.1108/02686900510592089

Singleton, T.W. (2011). How the IT auditor can make substantive contributions to a financial audit. ISACA Journal, 1, 1-3.

Straub, D., Limayem, M., \& Karahanna, E. (1995). Measuring system usage: Implications for IS theory testing. Management Science, 41, 1328-1342. http://dx.doi.org/10.1287/mnsc.41.8.1328

Taylor, S., \& Todd, P. A. (1995). Assessing IT usage: The role of prior experience. MIS Quarterly, 19, 561-570. http://dx.doi.org/10.1287/isre.6.2.144

Thnaibat, A. (2003) "Use and Usefulness of Information Technology in the Audit Process in Jordan”. Derassat, Business Administration, University of Jordan, 30, 253-268 (in Arabic).

Thompson, R. L., Higgins, C. A., \& Howell, J. M. (1991). Personal computing: Toward a conceptual model of utilization. MIS Quarterly, 15, 125-143. http://dx.doi.org/10.2307/249443

Venkatesh, V., \& Davis, F. D. (2000). A Theoretical Extension of the Technology Acceptance Model: Four Longitudinal Field Studies. Management Science, 46, 186-204. http://dx.doi.org/10.1287/mnsc.46.2.186.11926

Venkatesh, V., Morris, M. G., Davis, G. B., \& Davis, F. D. (2003). User Acceptance of Information Technology: Toward a Unified View. MIS Quarterly, 27, 425-478. http://www.jstor.org/stable/30036540

Williams, M. D., Dwivedi, Y. K., Lal, B., \& Schwarz, A. (2009). Contemporary trends and issues in IT adoption and diffusion research. Journal of Information Technology, 24, 1-10. http://dx.doi.org/10.1057/jit.2008.30

Walsh, S. T., \& White, C. G. (2000). Congress's goals of increasing electronic filing: An assessment based on the technology adoption literature. Accounting Horizons, 14, 403-426.

West, T. D., \& Davis, F. D. (2008). Antecedents and consequences of adoption performance-based budgets. Working Paper, Northern Illinois University.

World Economic Forum (2010), The Networked Readiness Index, the Global Information 
Technology Report 2009-2010, Geneva, Switzerland, p. 239.

Zhao, N., Yen, D. C., \& Chang, I. (2004). Auditing in the e-commerce era. Information Management \& Computer Security, $12, \quad 389-400$. http://dx.doi.org/10.1108/09685220410563360

\section{Copyright Disclaimer}

Copyright for this article is retained by the author(s), with first publication rights granted to the journal.

This is an open-access article distributed under the terms and conditions of the Creative Commons Attribution license (http://creativecommons.org/licenses/by/3.0/). 